\title{
Modifications of Connective Tissue Matrices by an Enzyme Extracted from Cartilage*
}

\section{A Histochemical, Autoradiographic, and Electronmicroscopic Investigation}

\author{
G. Quintarelli, S. SaJdera, and D. DziewiatKowski** \\ University of Alabama Medical Center, Birmingham, Alabama, and Regina Elena Institute \\ for Cancer Research, Rome, and The Rockefeller University, New York, N.Y.
}

Received May 10, 1968

Summary. The degradative properties of an enzyme extracted from bovine costal cartilage were studied histochemically, autoradiographically, and electronmicroscopically. Previous work had indicated that this enzyme catalyzes the degradation of proteinpolysaccharide, light fraction (PP-L) from bovine costal cartilage to a proteinpolysaccharide with a lower protein content than the original substrate. Attempts were therefore made to ascertain if this protease was species specific and if proteinpolysaccharides other than those present in cartilage were susceptible to enzyme digestion. To this end, the effect of the enzyme on human fetal cartilage and jaws and the epiphyseal plates of neonatal and postnatal rats was studied. Furthermore, ${ }^{35} \mathrm{~S}_{-} \mathrm{H}_{2} \mathrm{SO}_{4}$ was injected into pregnant rats, the fetuses were removed and sections of them were digested with the enzyme and then autoradiographed. In the histochemical experiments Alcian Blue with $\mathrm{MgCl}_{2}$ was used for the staining of tissue polyanions and Bromphenol Blue for the detection of free basic groups. Finally, the limbs of 20 day-old rats were utilized in electronmicroscopic studies.

Within the limitations of the techniques utilized the results obtained elucidated the following characteristics of the action of the enzyme on the tissues: 1 . the products resulting from the action of this protease are more soluble than the proteinpolysaccharides originally present in the tissues, 2. the extent to which the enzyme affects the tissue depends directly on the state of maturation of the tissue and, therefore, on the state of aggregation of the matrix, and 3. the enzyme is not species or tissue specific.

Autoradiograms of sections incubated with the enzyme also indicate an enhanced solubility of proteinpolysaccharides.

The effects of the enzyme on ultrathin sections were manifested in an increased affinity for phosphotungstic acid staining of the extrafibrillar matrix and of particles in the lacunae of degenerating chondrocytes. The latter showed a distribution similar to that of particles seen in semithin sections stained with Azure A.

\section{Introduction}

The maintenance of a tissue depends on a number of metabolic processes among which are the synthesis and catabolism of biopolymers. There is considerable information on the biosynthetic pathways involved in the production of the macromolecules of the non-fibrillar matrix of connective tissues (DoRFMAN, Roseman, Moses, Ludowieg, and Mayeda, 1955; D'Abramo and Lipmand, 1957 ; Markowitz, Cifonelli, and Dorfman, 1959; Leloir and Cardini, 1960; Guick and Stockdale, 1964). In contrast, much less is known of the processes whereby these macromolecules, the proteinpolysaccharides, are catabolized.

* Supported by Grant DE-02110-03-04 of the National Institutes of Public Health, Bethesda, Md.

** Present Address: University of Michigan, School of Dentistry, Ann Arbor, Michigan. 
A suggestion that endogenous enzymes might be involved in the depolymerization of proteinpolysaccharides was made by ErNBINDER and ScHubERT (1950) and by Malawista and Schubert (1958). These authors made the interesting observation that when cartilage was stored in the cold for several weeks more chondroitin sulfate could be extracted than if fresh cartilage were used. These observations suggested that somehow during storage the polysaccharide was being dissociated from protein.

Thомas (1956) demonstrated the dramatic effects of intravenous injections of papain on the auricular and other cartilages of young rabbits. Tsaltas (1958) and others (BRYANT et al., 1958; PoTTER et al., 1960) also showed that papain released chondromucoproteins from the cartilaginous tissues. Prior to Thomas' experiments, Fell and Mellanby (1952) reported that the addition of vitamin A in excess to an explant of embryonic cartilage promoted the release of metachromatic material into the medium. In collaboration, Fell and Thomas (1961) obtained additional experimental evidence which led them to suggest that vita$\min \mathrm{A}$ in excess promoted the activation or the release of a proteolytic enzyme and that this enzyme showed a papain-like action.

The discovery by DE Duve (1959) that certain cytoplasmic granules (lysosomes) contain several latent acid hydrolases prompted LuCY, DINGLE, and FeLL. (1961) and Dingle $(1961,1963)$ to seek a protease maximally effective at an acid $\mathrm{pH}$. Their experiments, suggesting that such enzymes did exist and that they could catalyze the breakdown of cartilage matrix, opened new avenues of investigation into the problem of how the ground substance of connective tissues may be degraded. Further evidence for the presence of a protease in cartilage capable of degrading and thereby promoting the release of chondromucoproteins from cartilage was provided by ALI (1964). He showed that there was an increase in the glucuronic acid content of the medium in which auricular cartilage was incubated, if the medium contained an extract of similar cartilages. Furthermore, the solubilization of glucuronic acid-containing material was inhibited by arginine esters. On the basis of his observations, ALI suggested that the protease resembled cathepsin B (1967). In an endeavor to gain more knowledge of the mechanisms operative in endochondral ossification, Tourtellotte, Campo, and Dziewiatkowski (1963) and Dziewiatkowski, Tourtellotte, and Campo (1967) looked for an enzyme in bovine costal cartilage which might catalyze the degradation of chondromucoproteins. They too found a protease effective in the transformation of PP-I. (proteinpolysaccharide, light fraction of GERBER, Frankin, and SCHUBERT, 1960) to a proteinpolysaccharide with a decreased protein content. Additionally, the latter was more soluble in water or in salt solutions than the former. As an outgrowth of these investigations it seemed of interest to establish the effects of this enzyme, which we will call CMPase, on connective tissue proteinpolysaccharides in general, as they are found in situ.

\section{Materials and Methods \\ 1. Isolation of the Enzyme}

The costal cartilages of recently slaughtered calves were exeised, freed of all non-cartilaginous tissue, including perichondrium, and shaved into strips $0.5 \mathrm{~mm}$ thick or less. The shavings of cartilage were extracted with ten volumes of toluene-saturated distilled water at 
$4^{\circ} \mathrm{C}$ for 48 hours, then re-extracted in the same way. The extracts were lyophilized before storage at $-15^{\circ} \mathrm{C}$.

CMP accounts for the bulk of the lyophilized materials. Even 1\% solutions are too viscous to handle according to the usual methods employed for protein isolation and purification. Consequently, it was found expedient to begin purification by precipitating CMP with either protamine sulfate or cetylpyridinium chloride (CPC). The latter is the more satisfactory precipitant because it can easily be removed if present in excess.

A $5 \%(\mathrm{w} / \mathrm{v})$ suspension of the lyophilized extracts in Buffer $\mathrm{I}(0.05 \mathrm{M} \mathrm{KCl}, 0.005 \mathrm{M}$ sodium cacodylate, $\mathrm{pH}$ adjusted to 7 with $\mathrm{HCl}$, saturated with toluene) was dialyzed against Buffer I to equilibrium at $4^{\circ} \mathrm{C}$. The retentate was warmed to $20^{\circ} \mathrm{C}$ and titrated to a flocculent endpoint with a $10 \%(\mathrm{w} / \mathrm{v})$ solution of CPC in Buffer I; approximately 2.5 moles of CPC per mole of uronic acid in the retentate were required. The resulting CPC-CMP precipitate was removed by centrifugation $(30,000 \mathrm{~g}$-min) and discarded. The supernatant solution was chilled to $0^{\circ} \mathrm{C}$, precipitating most of the excess $\mathrm{CPC}$, and filtered through medium porosity sintered glass at $4^{\circ} \mathrm{C}$. The small amount of $\mathrm{CPC}$ remaining in the filtrate was removed by dialysis against Buffer I at $20^{\circ} \mathrm{C}$ for $6-12$ hours; the salt content of the retentate was then reduced by further dialysis at $4^{\circ} \mathrm{C}$ against 10 volumes of distilled water saturated with toluene. Lyophilization yielded a preparation containing less than $1 \%$ uronic acid, designated "crude CMPase".

The crude CMPase was further purified by gel filtration through Sephadex G-25, followed by gel filtration through G-200. In each case solution and elution were with Buffer I. In the former case, the enzyme was eluted in the void volume, while in the latter case it was retarded. In both cases, analysis of the absorbance of the effluent at $280 \mathrm{~m} \mu$, and of its CMPase activity assessed according to Dziewiatkowski, Tourtellotte, and Campo (1967), indicated that CMPase activity had been separated from other proteinaceous materials. Effluent fractions containing CMPase were combined, dialyzed against distilled water saturated with toluene, and lyophilized. Such lyophilizates are designated "purified CMPase" and were obtained in yields of about $40 \mathrm{mg}$ per $\mathrm{kg}$ of costal cartilage.

\section{Histochemistry}

Ribs, tracheas, femurs, tibias, and lower jaws taken from three and five month human fetuses collected at the delivery table, and fragments of tracheal rings from a tracheotomized 20 year-old patient, were cut into small pieces and fixed in a solution of 1 part formalin and 9 parts absolute alcohol at $4^{\circ} \mathrm{C}$ for $\mathbf{2 4 - 3 6}$ hours. Undecalcified epiphyses from 3 day-old rats were also used after fixation in the above solution. Subsequently the tissues were immersed in 2 changes of cold absolute alcohol for 24 hours each time, cleared in xylene, and embedded in paraffin. Serial sections were cut, spread onto slides, deparaffinized, and hydrated in the usual fashion, and then dried. The sections were incubated in either Buffer II $(0.1) M$ potassium acetate, $\mathrm{pH} 4.0$ ) containing $0.05 \%$ purified CMPase, or in Buffer II alone, for 18 hours at $37-38^{\circ} \mathrm{C}$. After incubation, the sections were rinsed several times in distilled water. Representative control and experimental sections were stained with Alcian Blue in one of two ways: 1. at $\mathrm{pH} 5.6$ in the presence of graded concentrations of magnesium chloride (QUINTARELLI and DeLlovo, 1965, 1966), or 2 . at $\mathrm{pH} 2.5$ in the presence of $2 M$ potassium chloride (QuintaRELli, Scott, and Dellovo, 1964). After thoroughly rinsing in distilled water, some of the slides were counterstained with PAS and hematoxylin according to Mowny (1963). Other control and experimental sections were stained with Bromphenol Blue according to BoNHAG (1955), a method presumed specific for the detection of free basic groups. Recrystallized Azure $A$ was used at $0.5 \%$ concentration in $0.01 M$ acetate buffer, $\mathrm{pH} 2.0$ and 4.2.

\section{Radiosulfate Incorporation and Autoradiography}

Each of four pregnant rats was given a single intraperitoneal dose of $2.5 \mathrm{mc}$ of carrier-free ${ }^{35} \mathrm{~S}_{-} \mathrm{H}_{2} \mathrm{SO}_{4}$ (Nuclear Science Engineering Corp., Pittsburgh, Pennsylvania) on the fifteenth day of pregnancy. Two of the rats were sacrificed with ether 2 hours later, and two, 4 hours later. The fetuses were removed during anesthesia and fixed, dehydrated, cleared, embedded, and sectioned as described above. The sections were then incubated in Buffer II, with or without enzyme, dried and coated by dipping them in a Kodak $\mathrm{NTB}_{2}$ photographic emulsion. 
Three days later these preparations were developed for five minutes in Kodak D-19 developer, rinsed for 1 minute in a $1 \%$ solution of acetic acid, and fixed in Kodak Acid-Fixer. The slides were washed in repeated changes of distilled water at $18^{\circ} \mathrm{C}$ with minimal agitation. They were dehydrated by passage through graded concentrations of ethanol, starting with $30 \%$ ethanol, cleared, and mounted.

Four 3 day-old rats were each given $100 \mu \mathrm{c}$ of carrier-free ${ }^{35} \mathrm{~S} \cdot \mathrm{H}_{2} \mathrm{SO}_{4}$ intraperitoneally and sacrificed by decapitation 4 hours later. The humeri were removed and fixed in an unbuffered $4 \%$ solution of formaldehyde for 24 hours at room temperature. After embedding in paraffin in the usual way, sections were cut at $5 \mu$ and single sections were affixed to glass slides. After removing the paraffin with xylene and drying, representative sections were counted, using a Geiger-Mueller tube with a mica window of $1.5 \mathrm{mg} / \mathrm{cm}^{2}$ thickness. Eight of the sections were then incubated at $37^{\circ} \mathrm{C}$ for 24 hours in coplin jars, each of which contained $25 \mathrm{ml}$ of a $0.05 \%$ solution of purified CMPase in $0.1 M$ potassium acetate buffer, $\mathrm{pH} 4$. An equal number of sections on slides were incubated similarly and concurrently in the buffer only. After rinsing in three changes of buffer and three changes of distilled water, each for 10 minutes, the sections were dried and recounted. They were then stained with Alcian Blue for two hours, using a dye bath which was $0.5 M$ in magnesium chloride, according to Qurntarelli and DeLLovo (1965). The stained sections, after dehydration and clearing in xylene, were dried and recounted. Corrections for decay of radioactivity were made. After clearing again in xylene, the sections were mounted.

A similar series of the humeri after incubation in a solution of CMPase or in the buffer were used for the preparation of autoradiograms as already described for the sections of the ${ }^{35} \mathrm{~S}_{\mathrm{S}} \mathrm{SO}_{4}^{-}$-labeled rat fetuses.

\section{Electronmicroscopy}

A cold $4 \%$ solution of formaldehyde prepared directly from paraformaldehyde and buffered at $\mathrm{pH} 7.3$ with phosphate according to MIrLONIG (1962) was injected into the hind limbs of 15- and 20-day-old rats under ether anesthesia. The limbs were excised and immersed in the fixative. Cubes of tissue about $1 \mathrm{~mm}$ on a side, comprehensive of both epiphyseal and metaphyseal structures, were cut out as quickly as possible. The tissue blocks were each transferred to small flasks containing $10 \mathrm{ml}$ of the fixative, in which they were kept for 1 hour at $4^{\circ} \mathrm{C}$. They were then rinsed several times with Millonig's buffer, passed through graded concentrations of glycolmethacrylate (GMA, Rohm and Haas; $50 \%, 70 \%, 80 \%$, and $96 \%$ ), and finally into prepolymerized GMA. Final polymerization was carried out at $60^{\circ} \mathrm{C}$ for 12-16 hours. Sections were eut with an MT2 Porter-Blum microtome at 1 micron thickness for examination at the light microscope level and at approximately $900 \AA$ for electron microscopy. The sections were collected in plastic rings directly from the knife trough according to Marinozzi (1964) in order to facilitate their transfer to watch glasses containing $6 \mathrm{ml}$ of purified CMPase in Buffer II or $6 \mathrm{ml}$ of Buffer II alone. After incubation for 1-2 hours at $38^{\circ} \mathrm{C}$ they were rinsed with six ten-minute changes of cold Buffer II. Representative control and experimental sections were mounted on copper grids, dried on filter paper, and stained with either 5\% uranyl acetate, with $\mathrm{Pb}$ (KARNOvsky, 1961), or 1\% phosphotungstic acid. These grids were examined in a Siemens Elmiskop 1 A. Representative 1 micron sections were mounted on slides and stained with either $1 \%$ Azure $\mathrm{A}$ at $\mathrm{pH} 2.0$ and 4.0, or with Bromphenol Blue. In some instances hyaluronidase (testicular, Worthington) was applied to semithin sections at $0.5 \%$ concentration buffered to $\mathrm{pH} 5.0$ with $0.1 M$ phosphate.

\section{Results \\ Histochemical}

In the absence of magnesium chloride or when the latter was present at low concentration, tracheal cartilage of the human fetuses stained strongly and uniformly with Alcian Blue. The basophilia of this tissue was in evidence up to a concentration of $0.6 M$ in magnesium chloride; it abruptly disappeared throughout the cartilaginous structure when the concentration of this salt in the dye bath 
was increased to $0.7 \mathrm{M}$. At this developmental stage the tissue was weakly stained by PAS or by Bromphenol Blue. The collagen fibers were the only elements of the tissue which reacted with the latter dye. This has been reported previously (Quintarelli and Dellovo, 1966).

The basophilia of the untreated sections of the tissues differed in no way from that found for the sections incubated in buffer only and utilized as controls. On the other hand, CMPase digested sections were more strongly stained with Alcian Blue at pH 2.5 than were the controls. However, when Alcian Blue was used in the presence of graded concentrations of magnesium chloride at $\mathrm{pH} 5.6$, control sections showed no loss of basophilia until the electrolyte concentration reached 0.6 M (Fig. 1), while the CMPase-digested sections showed diminution of alcianophilia at far lower salt concentrations (Fig. 2). After staining in dye baths which were $0.5 M$ in magnesium chloride, the difference between enzyme-digested and the buffer-incubated sections was striking; the former were only faintly stained but the latter were a deep shade of blue.

The uptake of Bromphenol Blue by sections incubated with the enzyme was enhanced (compare Fig. 3 with Fig. 4). This was the case whether the human tracheal cartilage was prenatal or from the 20 year-old individual. There was, however, a striking difference in the staining pattern of the cartilage of these two age groups. In the prenatal cartilage the dye was distributed over the whole of the matrix, regardless of the histological area. In the 20 year-old cartilage the territorial and interterritorial regions were differentially stained. It was quite evident, in fact, that the territory of the small isogenic groups of cells in the deep portion of the segments was far more heavily stained than the remainder of the matrix (compare Fig. 5 with Fig. 6).

In human fetal femurs and tibias numerous vascular canals were found in regions of proliferating cartilage as well as adjacent to the hypertrophic cells. In these tissues the matrix was homogeneously basophilic. When stained in dye baths containing magnesium chloride, a slight but consistent reduction in the uptake of Alcian Blue was found when the concentration of the salt was $0.6 M$ and no basophilia was in evidence when the concentration of the salt was $0.7 M$. These tissues were weakly stained with PAS, suggesting that in these young cartilages large amounts of glycoproteins are not synthesized. When Bromphenol Blue was used, the sections were unstained.

After incubation in the potassium acetate buffer at $\mathrm{pH} \mathrm{4.0,} \mathrm{the} \mathrm{staining}$ characteristies of sections of fetal femurs and tibias differed in no way from those of untreated sections. However, sections which had been incubated with the enzyme showed modifications in staining similar to those described above for human tracheal cartilage. In these tissues as well, alcianophilia was enhanced at $\mathrm{pH} 2.5$, while at $\mathrm{pH} 5.6$ it was eliminated at a lower magnesium chloride concentration than that required in the case of the control sections. An electrolyte concentration of only $0.1 \mathrm{M}$ magnesium chloride effected a remarkable reduction in basophilia whereas at $0.2 \mathrm{M}$, its complete elimination was obtained (Figs. 7 and 8). After incubation with the enzyme the uptake of Bromphenol Blue by the sections was enhanced, while the PAS reactions of the experimental and the control sections were both exceedingly weak. 


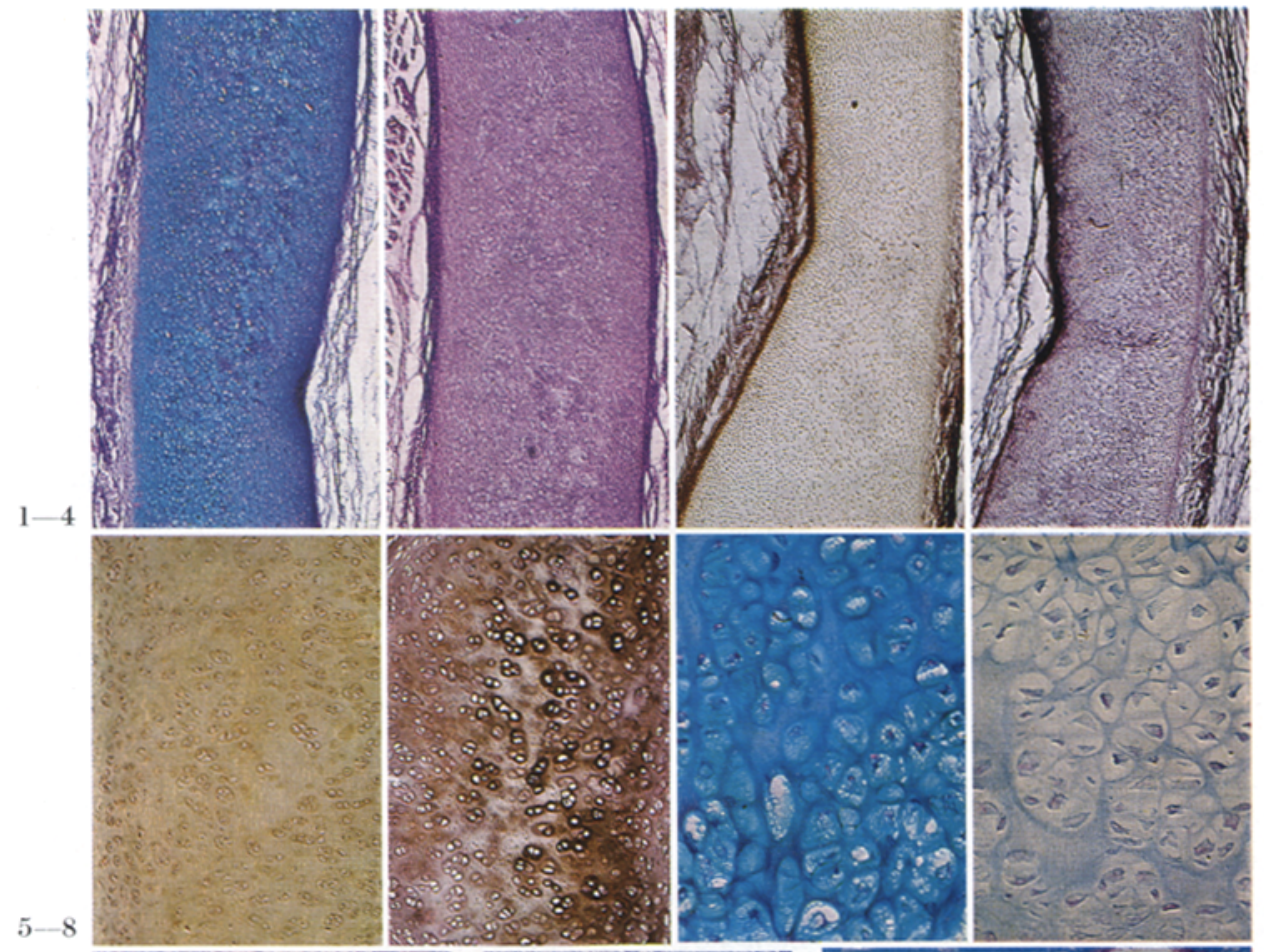

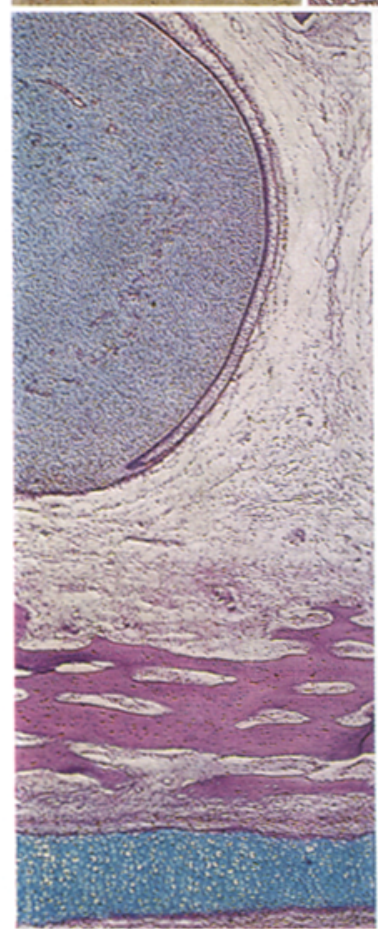

9

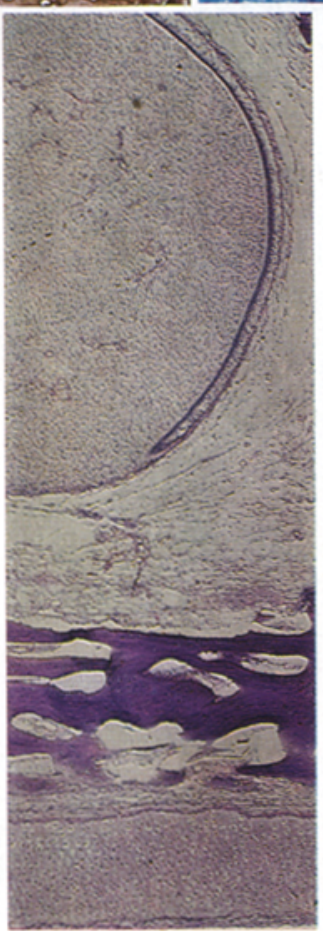

10

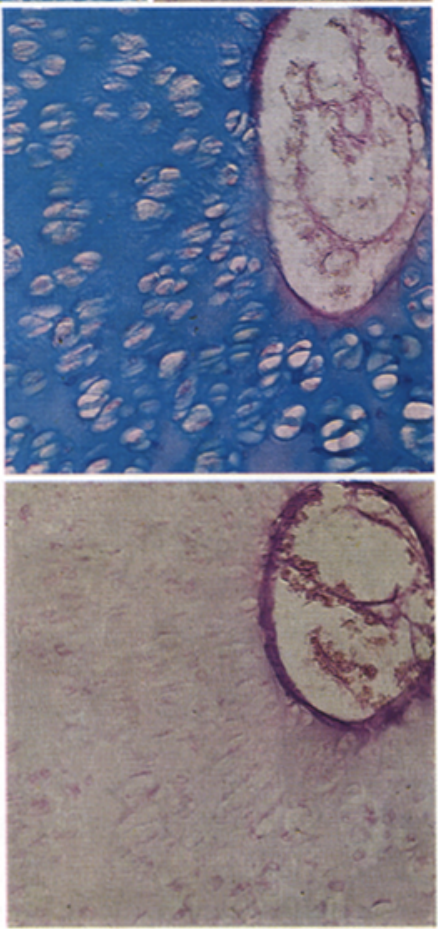

12

Figs. 1-12 
The molar region of a lower jaw removed from a 3 month-old fetus was also examined in some detail. At this stage of histodifferentiation the outer and the inner enamel epithelia and the stellate reticulum are well developed and the basal membrane, separating the inner enamel epithelium from the cells of the pulp, is differentiated. The basophilia of these structures has been documented (HoLMGREN, 1940; WISLOCKI and SOGNNAES, 1950; inter alia) and need not be emphasized further, except to note that, when the Alcian Blue-PAS sequence of staining is utilized, cartilage, dental pulp, and stellate reticulum are all stained by the phthalocyanin derivative, while only bone reacts positively with PAS.

In studying this composite tissue a difference in the affinity of cartilage, dental pulp, and stellate reticulum for Alcian Blue was found. The stellate reticulum

Fig. 1. Five month old human fetal trachea. AB-PAS-Hematoxylin. $0.6 \mathrm{M} \mathrm{MgCl} 2$ added. Control section incubated in buffer alone for $18 \mathrm{hr}$ at $37^{\circ} \mathrm{C}$. Strong basophilia throughout the skeletal segment

Fig. 2. Serial section of Fig. 1. AB-PAS-Hematoxylin. $0.6 \mathrm{M} \mathrm{MgCl}_{2}$ added. Experimental. Section incubated in the enzyme for $18 \mathrm{hr}$ at $37^{\circ} \mathrm{C}$. The alcianophilia is abolished completely

Fig. 3. Five month old human fetal trachea. Bromphenol blue staining. Control. Section incubated in buffer alone for $18 \mathrm{hr}$ at $37^{\circ} \mathrm{C}$. Note the total lack of staining in the matrix

Fig. 4. Serial section of Fig. 3. Bromphenol blue. Experimental. Section incubated in the enzyme for $18 \mathrm{hr}$ at $37^{\circ} \mathrm{C}$. After enzyme hydrolysis an intense and homogeneous staining of cartilage has ensued

Fig. 5. Twenty year old human trachea. Bromphenol blue. Control section incubated in buffer alone for $18 \mathrm{hr}$ at $37^{\circ} \mathrm{C}$. Negative staining of the matrix

Fig. 6. Twenty year old human trachea. Bromphenol blue. Experimental. Section incubated in the enzyme for $18 \mathrm{hr}$ at $37^{\circ} \mathrm{C}$. Notice the intense staining of the ground substance and the selectivity of bromphenol blue-reacting material in the territory of several chondrocytes

Fig. 7. Five month old human fetal tibia. AB staining. $0.2 \mathrm{M} \mathrm{MgCl}$ added. Control. Section incubated in buffer alone for $18 \mathrm{hr}$ at $37^{\circ} \mathrm{C}$. Strong staining of the matrix

Fig. 8. Serial section of Fig. 7. $\mathrm{AB}$ staining. $0.2 \mathrm{M} \mathrm{MgCl}_{2}$ added. Experimental. Section digested for $18 \mathrm{hr}$ at $37^{\circ} \mathrm{C}$. Although the CEC for the reversibility of this complex usually occurs between $0.7 M$ and $0.8 M$, after enzyme digestion it was greatly reduced

Fig. 9. Three month old human fetal jaw. AB-PAS-Hematoxylin. $0.5 M \mathrm{MgCl}_{2}$ added. Control. Incubated in buffer for $18 \mathrm{hr}$ at $37^{\circ} \mathrm{C}$. Substantive alcianophilia may be seen both in cartilage and in the dental papilla

Fig. 10. Serial section of Fig. 9. AB-PAS-Hematoxylin. 0.5 $\mathrm{M} \mathrm{MgCl}_{2}$ added. Experimental. Incubated in the enzyme for $18 \mathrm{hr}$ at $37^{\circ} \mathrm{C}$. Complete disappearance of basophilia from cartilage as well as from the dental papilla

Fig. 11. Five month old human fetal femur. AB-PAS. 0.6 $M \mathrm{MgCl}_{2}$. Control. Section incubated in buffer for $18 \mathrm{hr}$ at $37^{\circ} \mathrm{C}$. Note the strong basophilia of cartilage matrix. In the upper left corner of the picture a large oval vascular canal may be seen

Fig. 12. Serial section of Fig. 11. AB-PAS. 0.6 $M \mathrm{MgCl}_{2}$. Experimental. Section digested in the enzyme for $18 \mathrm{hr}$ at $37^{\circ} \mathrm{C}$. Only PAS reactive substances are left in the matrix as tissue basophilia is no longer present at this molarity of salt 
was not stained in dye baths containing magnesium chloride at a concentration of $0.1 \mathrm{M}$, the staining of the dental pulp was only slightly reduced, and the staining of the cartilage was unaffected. On increasing the molarity of this salt, the basophilia of the dental pulp was progressively reduced, completely so at $0.5 M$, but the affinity of cartilage for the dye was unchanged. Only in dye baths which were $0.6 \mathrm{M}$ in magnesium chloride did the cartilage show loss of basophilia.

The various histological structures of the jaw also reacted differently with Bromphenol Blue. The uptake of this dye was highest in bone, while the dental papilla and stellate reticulum were stained weakly and the cartilage was unstained.

The pattern of staining after incubation with the enzyme was essentially as described for the other tissues. The only difference was that reversal of alcianophilia for CMPase-treated jaw structures took place at even lower concentrations of magnesium chloride than those required by the tissues considered above. In the case of the jaw an almost parallel decrease in dye binding by the cartilage and the dental pulp was found in the presence of $0.1 \mathrm{M}$ magnesium chloride. However, the critical electrolyte concentration (CEC) for the complete elimination of the basophilia of the dental pulp was lower than the CEC needed for the cartilage (Figs. 9 and 10). Staining with Bromphenol Blue was enhanced again.

In a previous study of epiphyseal plates from 3 day-old rats, the CEC at which the interaction of Alcian Blue with this tissue's components was completely eliminated was established at $0.7 \mathrm{M}$ in magnesium chloride (QUINTARELLI and DeLLovo, 1965). In the present study it was found, as has been reported for other tissues, that when sections were digested in the enzyme, basophilia was eliminated at much lower concentrations of electrolytes (Figs. 11 and 12).

The epiphyseal cartilage stained with Bromphenol Blue in a manner generally similar to that of the other cartilaginous structures. However, a striking difference was seen in the regions of the hypertrophic chondrocytes; there was a noticeably enhanced uptake of the dye by the provisionally calcified cartilage.

\section{Autoradiographic}

Sections of the 15 day-old fetuses and of the 3 day-old rats given ${ }^{35} \mathrm{~S}=\mathrm{H}_{2} \mathrm{SO}_{4}$, after incubation with the enzyme, produced autoradiograms which were less

Table. Differential loss of ${ }^{35} \mathrm{~S}$-labeled materials from sections of humeri during incubation with CMP-ase and during staining with alcian blue in the presence of magnesium chloride at $0.5 \mathrm{M}$ concentration

\begin{tabular}{lll}
\hline & $\begin{array}{l}\text { Experimental } \\
\% \text { of original }\end{array}$ & $\begin{array}{l}\text { Control } \\
\% \text { of original }\end{array}$ \\
\hline After incubation & $74(72-75)$ & $85(86-89)$ \\
After staining & $48(47-48)$ & $73(71-75)$ \\
\hline
\end{tabular}

The mean values and the ranges of values of eight sections are given. The sections of humeri were from 3 day-old rats, each given $100 \mu \mathrm{c}$ of carrier-free ${ }^{35} \mathrm{~S}_{-} \mathrm{H}_{2} \mathrm{SO}_{4}$ and sacrificed 4 hours thereafter. Fixation of the tissue was in unbuffered 4 per cent formalin.

Incubation was for 24 hours at $37^{\circ} \mathrm{C}$ in $0.1 \mathrm{M}$ potassium acetate buffer, $\mathrm{pH} \mathrm{4}$, (Controls) or in the same buffer with CMP-ase (Experimental). 


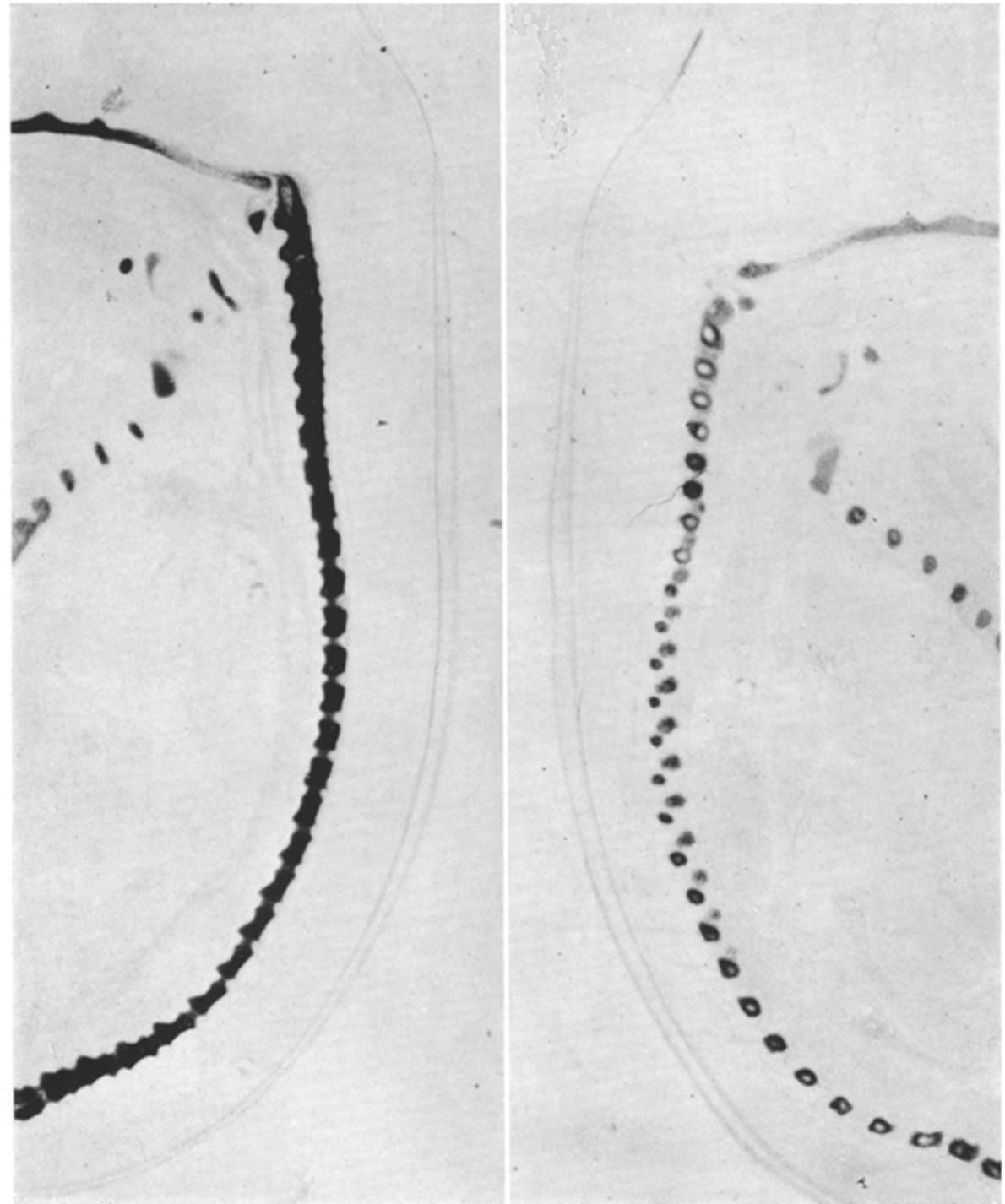

Fig. 13

Fig. 14

Fig. 13. Fifteen day old rat fetus. Section incubated in buffer for $18 \mathrm{hr}$ at $37^{\circ} \mathrm{C}$. Strong sulphate labeling of all body cartilages

Fig. 14. Serial section of Fig. 13. Incubation in the enzyme for $18 \mathrm{hr}$ at $37^{\circ} \mathrm{C}$. Note the over-all diminution of silver grains from the section and the discrete bands of labeled material leaving vertebral cartilage

intense than those produced by the control sections (Figs. 13-18). In the case of the fetuses, various cartilages were evidently affected. Of interest in the autoradiograms of the enzyme-treated sections was the presence thereon of streaks 

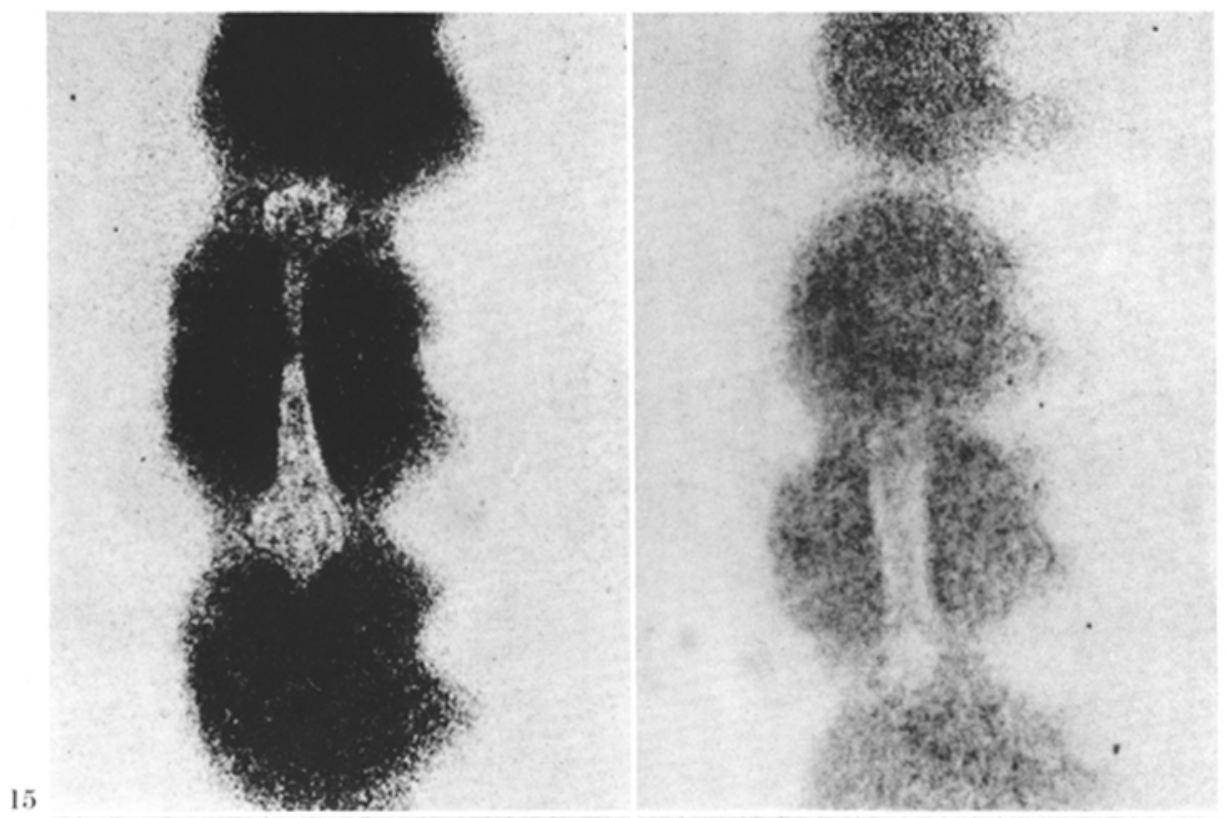

16
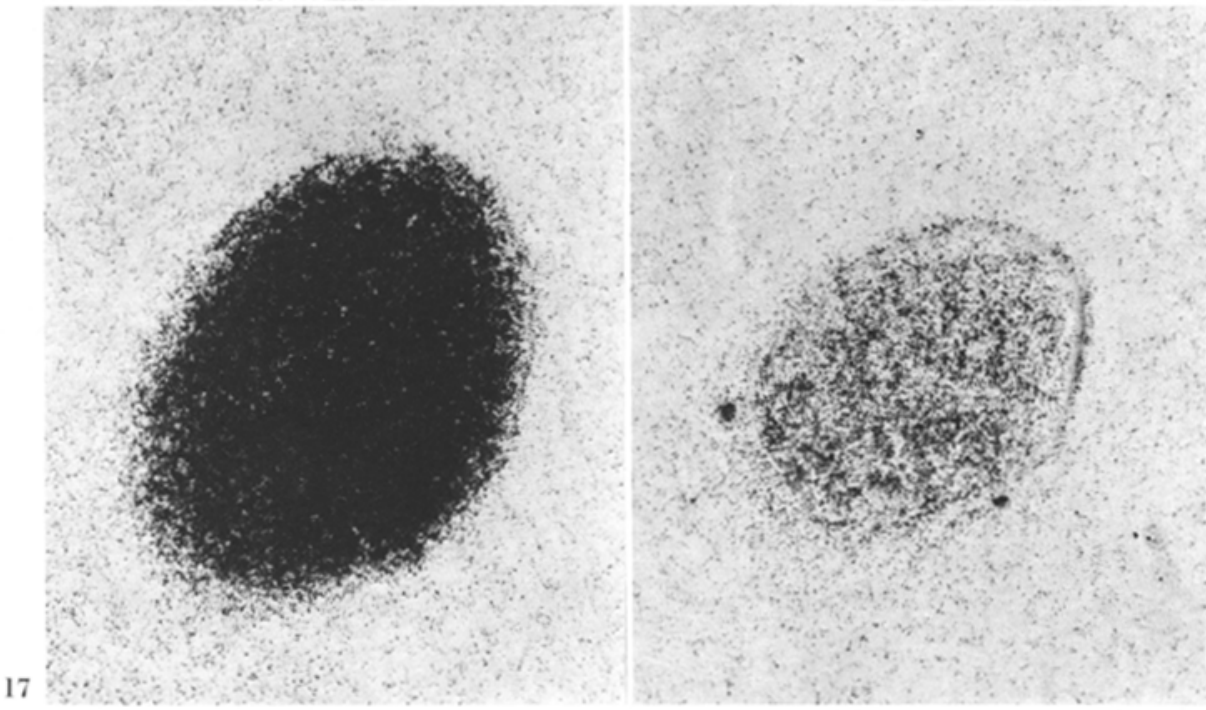

Fig. 15. High power view of vertebral cartilage. Control

Fig. 16. High power view of vertebral cartilage. Experimental

Fig. 17. Fragment of costal cartilage. Control

Fig. 18. Fragment of costal cartilage. Experimental

which had their origins in various cartilages; it was noted that these streaks flowed as the photographic emulsion flowed during its drying period, after dipping the slides. This observation can best be understood after reference to the results 


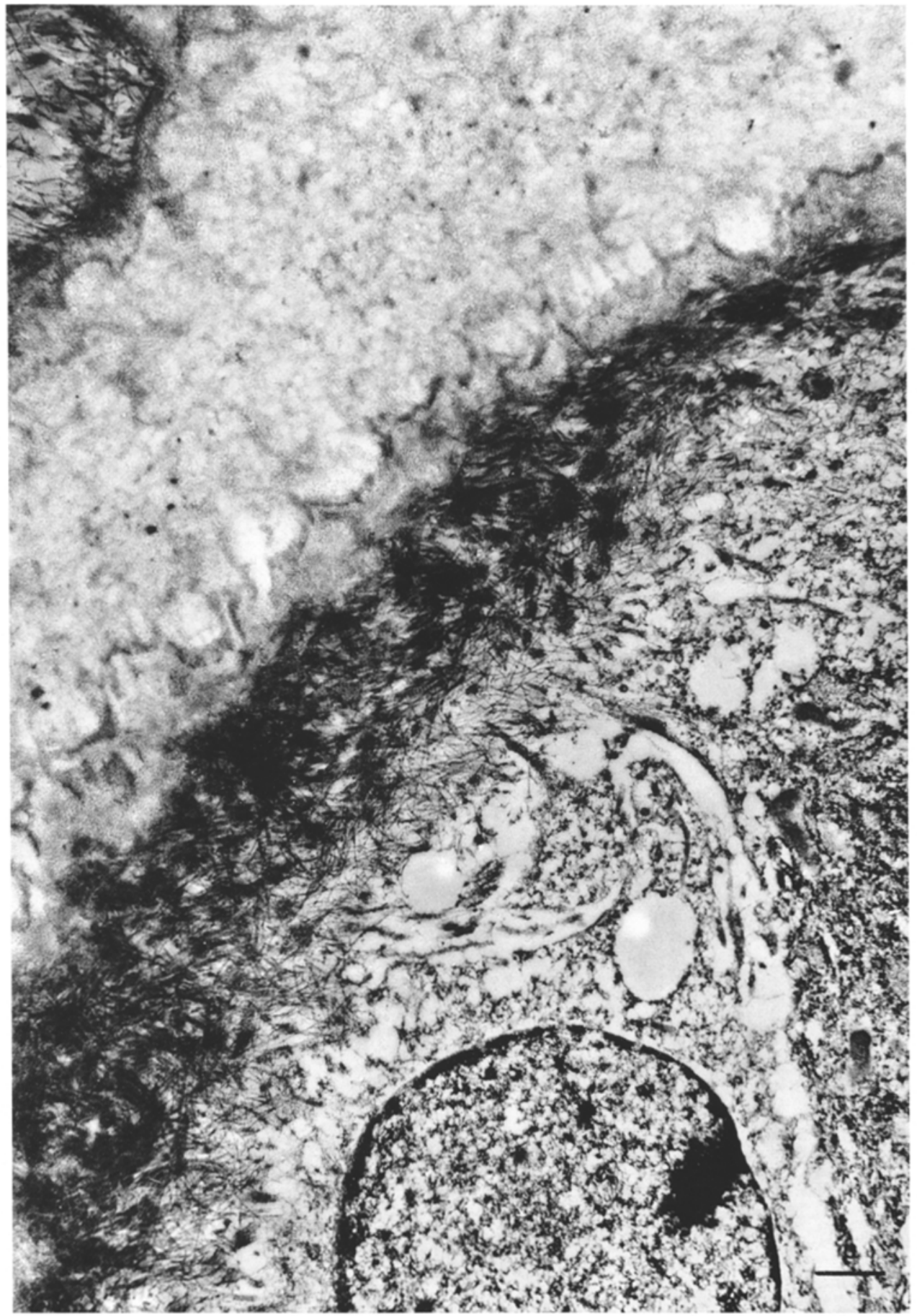

Fig. 19. Electronmicrograph of an osteoblast and of the osteoid matrix. This section was incubated in $\mathrm{K}$ acetate buffer for $2 \mathrm{hr}$. As expected the osteoid matrix shows no electron density. $\mathrm{Ur} / \mathrm{Pb} . \times 9000$ 


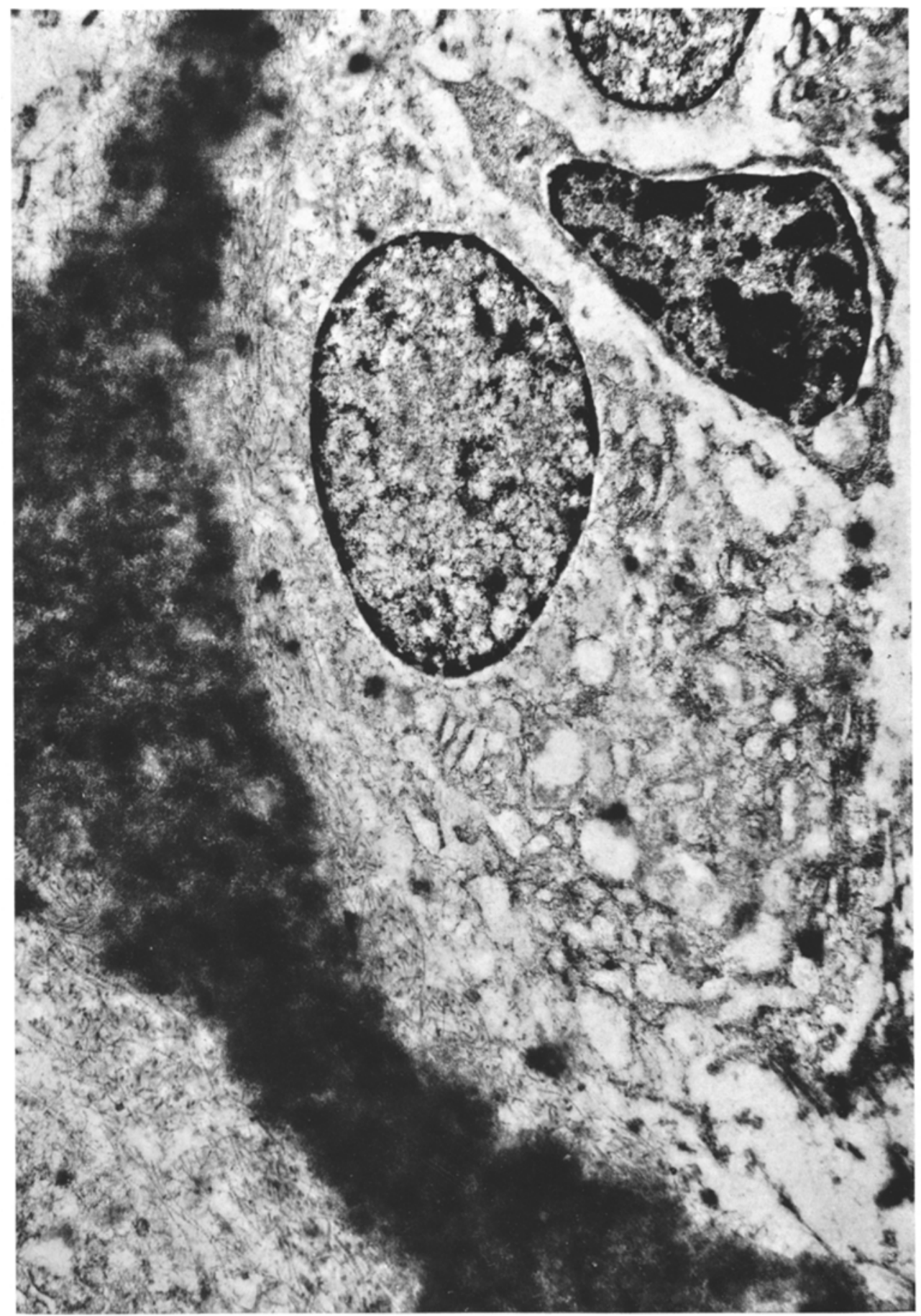

Fig. 20. Serial section of Fig. 19 digested in the enzyme, rinsed several times in buffer and stained. Note the osteoid intensely electron dense. The inereased staining is extremely regular and only involves the extracellular matrix. $\mathrm{Ur} / \mathrm{Pb} . \times 9000$ 


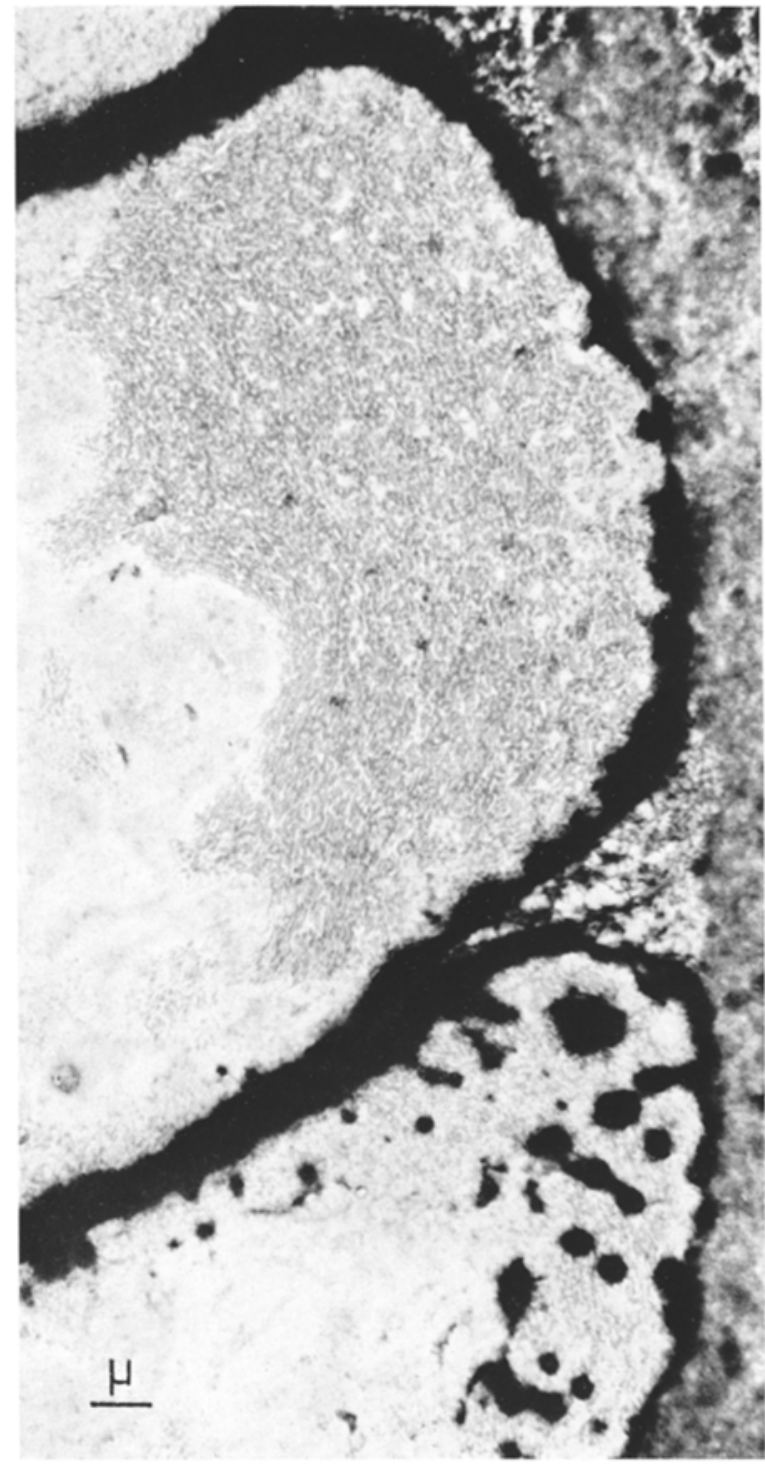

Fig. 21

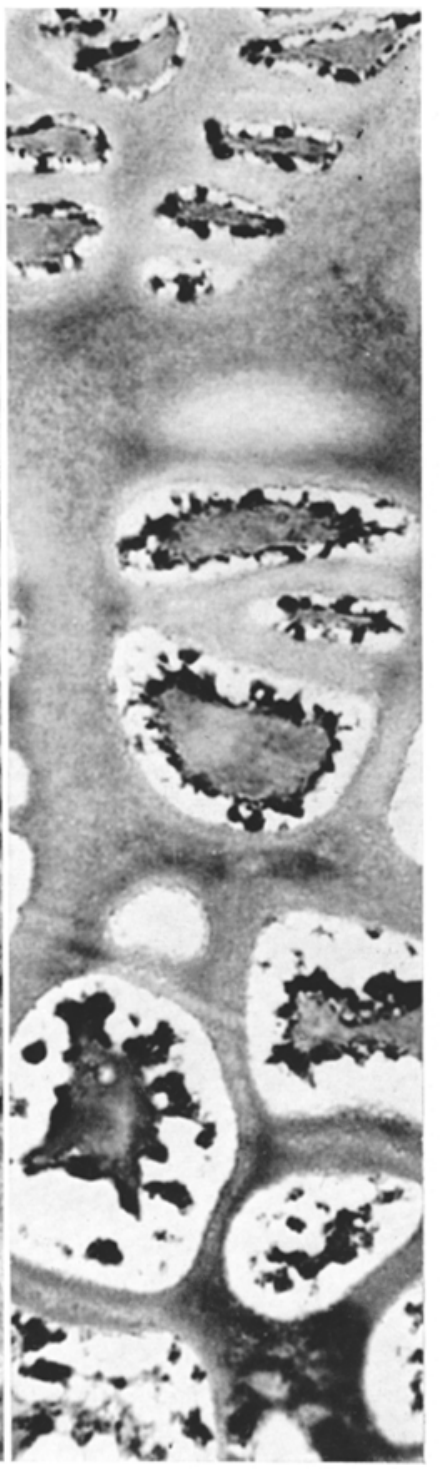

Fig. 22

Fig. 21. Section of hypertrophic cartilage exposed to enzyme treatment for $2 \mathrm{hr}$. The matrix of the lacunar rim is intensely electron dense. Note the deeply "colored" granules in the cavity. PTA. $\times 6000$

Fig. 22. 0.8 micron section stained with azure A, pH 4.0. The metachromatic granules, representing chondromucoprotein, are identical to those revealed by phosphotungstic acid in Fig. $21 . \times 2200$

summarized in the Table, which demonstrates that digestion of these tissues with CMPase facilitates the loss of labeled material from them, both in the course 
of digestion and during the staining process. In this series of experiments, the sections incubated with the enzyme were less intensely stained with Alcian Blue than their counterpart controls; the difference was readily discernable, but the alcianophilia was not eliminated completely at a concentration of $0.5 M$ magnesium chloride.

\section{Electronmicroscopic}

Following incubation with the enzyme there were striking changes in the reactivity of the extracellular matrix with phosphotungstic acid and with the other metal salts. That is to say that in all regions of the epiphyseal cartilages there was a pronounced increase in electron density of the matrix and of the osteoid border, suggesting that some of the macromolecules had undergone a chemical change (Figs. 19, 20). Although control tissues were incubated in the same buffer solution as that used for enzyme-treated tissues, no modifications in the "staining" of the extracellular matrix were observed.

Furthermore, after incubation with the enzyme, the tissue was characterized by the intense blackening of the pericellular moats in the hypertrophic zones and of the electron-dense granules adjacent to the lacunar rims. Interestingly these granules, which could be best visualized after CMPase digestion, are similarly distributed as those observed in semithin sections after staining with Azure A (Figs. 21, 22). It was remarkable that after hyaluronidase digestion the azurophilia of these granules completely disappeared.

\section{Discussion}

It has been reported that proteolytic enzymes effect the partial or complete loss of basophilia of connective tissues (Fell and Mellanby, 1952; Thomas, 1956; Lucy, Dingle, and Fell, 1961). Such loss has been interpreted as due to the hydrolysis of proteinpolysaccharides and their subsequent release of the resultant fragments. These findings, although obtained on chondromucoprotein (i.e. on the proteinpolysaccharide complex as it is found in the tissue), are in keeping with the documented chemical and physical properties of PP-L (proteinpolysaccharide, light fraction) and the changes brought about when it is treated with CMPase. Many workers have reported that PP-L isolated from a variety of sources consists predominantly of sulfated glycosaminoglycans intimately associated with $10 \%$ to $20 \%$ of non-collagenous protein. A proposed model for the structure of CMP is one of protein "core" with polysaccharide chains attached to it through a variety of covalent linkages (see, for example, Hofrman et al., 1967). Although the molecular weights of the macromolecules are large (estimates up to $50 \times 10^{6}$ ), the molecular weights of the polysaccharide chains are relatively small $\left(15-30 \times 10^{3}\right)$. Such a model explains why proteolytic enzymes rapidly convert native PP-L to relatively low molecular weight fragments without chemically modifying the polysaccharide component. Products recovered after limited digestion of PP-L with CMPase exhibit a reduced protein content, have a decreased molecular weight, and dissolve more readily in aqueous solutions, when compared to the native PP-L (Tourtellotte, Dziewiatkowski, and Campo, 1963; Dziewiatkowski, Tourtellotte, and Campo, 1967). In the present experiment the extent of enzyme cleavage varied greatly, depending 
upon the type and the age of the tissue. In this work such a difference in lability was particularly apparent when prenatal and adult cartilages were compared. In other experiments (QuINTARELLI and Dellovo, 1966), in which papain, pronase $B$, pepsin, and trypsin were used, the staining characteristics of fetal tissues were drastically altered even on brief incubation, whereas extended periods of incubation were required for adult tissues. This lability of the fetal tissues may well be due to an incomplete polymerization of proteinpolysaccharides and/or to the extent of their aggregation with other components of the matrix (Gross, Mathews, and Dorfman, 1960; Quintarelli and Dellovo, 1966). In this regard, Rosenberg, Johnson, and Schubert (1965) found that PP-L isolated from cartilages of infants less than one year old, had the lowest protein content when compared with similar preparations from older individuals. In an analytical study on content and character of proteinpolysaccharides at different ages, Mathews and GLagov (1966) found that the chondroitin sulfate of human fetal cartilage is undersulfated and probably is part of a proteinpolysaccharide of low molecular weight. It appears that in very young tissues the chondromucoproteins are more soluble and more susceptible to enzymatic hydrolysis than are those in adult matrices.

In the experiments described here, the effects of CMPase (an acid protease which degrades chondromucoproteins but has no effect on collagen) on various connective tissues were studied using primarily Alcian Blue in combination with magnesium chloride, supplemented by autoradiography and electronmicroscopy. The affinity of the dye Alcian Blue for a substrate is a reflection of the attraction between oppositely charged entities. This interaction can be reversed if the concentrations of electrolytes in the dye bath are sufficiently high. Such a critical concentration of electrolytes (CEC) for the solubilization of the dye-substrate complex depends on the type of charge carried by the polyanion, on the charge density (SCOTT, DORLING, and QUINTARELII, 1964), and on the molecular weight of the molecule (LaURent and ScotT, 1964). Thus, whenever an Alcian Bluepolyanion complex is solubilized at a concentration of salt lower than the one established in a model tissue system, it is assumed that either the molecular weight of the polyanion is decreased and/or that its charge density is decreased. There, of course, is at least one other possibility, namely, that the concentration of the polyanion has been lowered. The applicability of this general principle in practice has been investigated (QUINTARELLI and Dellovo, 1965). Furthermore, using rat joints, it was found that the CEC for the chondromucoprotein-dye complex, established at $0.7-0.8 M$ magnesium chloride, decreased gradually with time when sections of the joints were kept in decalcifying solutions (QUINTARELLI and Dellovo, 1965). This was interpreted as due to the progressive removal of chondroitin sulfate and/or chondromucoprotein from the tissue. Similar results were obtained in the present investigation when CMPase-treated sections were compared with their controls. In all cases a consistent diminution of basophilia was seen in the enzyme-treated sections at molarities of magnesium chloride far lower than the molarities at which this occurred with sections incubated in buffer alone or untreated. Moreover, the fact that the CEC varied depending on the tissue and its age suggests that the proteinpolysaccharides are heterogeneous and/ or heterogeneously associated with other tissue components. 
The human fetal jaw may be taken as an example in which heterogeneity can be seen. It is a composite structure, comprehensive of two proteinpolysaccharide-rich tissues of mesenchymal origin, cartilage and dental papilla, and of a tissue of ectodermal origin, the stellate reticulum. The dental papilla and the cartilage were affected differentially by CMPase; in the former, staining with Alcian Blue was eliminated at molarities of magnesium chloride lower than those required for the cartilage. And yet, it had been established previously that the basophilia of untreated fetal dental pulp is eliminated at a CEC suggestive of sulfated polyanions comparable to those in the cartilage. Indeed, the metachromasia and the alcianophilia of the dental pulp were no longer demonstrable if this tissue had been digested with hyaluronidase (QuintaReluI and DeLlovo, 1963) and, from this it was inferred that the acid glycosaminoglycans present were chondroitin-4-sulfate and/or chondroitin-6-sulfate. The dental papilla is a relatively immature tissue, made up of undifferentiated mesenchymal cells; it retains this characteristic of immaturity throughout its life. The fetal jaw, therefore, may be regarded as an ideal model system for the study of tissues which, although of the same chronological age, are at different stages of histodifferentiation. It is suggested that the dental papilla and the adjacent eartilage were affected differentially by the CMPase because the proteinpolysaccharides in the dental papilla might be more soluble than those in the cartilage. Thus we may safely conclude at this point that one effect of CMPase on the connective tissues studied is to enhance the solubilities of their proteinpolysaccharides; by analogy with the effects of the enzyme on isolated PP.L, it is likely that the increased solubility results from a depolymerization of the tissue polyanion-protein molecular structure.

The fact that adult cartilage was not modified as drastically by the CMPase as was the fetal cartilage may be a reflection of a more complex or a more advanced state of aggregation of the components of the matrix in the former than in the latter tissue. It has been reported (AMPrino and BAIRATI, 1933) that in human costal cartilage changes suggestive of deterioration are initially apparent in the 12th to the 15th year of life, i.e. before the full development of the soma. More recently, it was shown that at this age period, but not before, keratansulfate can be identified histochemically in costal cartilage (Quintarelut and Dellovo, 1966). Usually, when such an identification can be made, proteolytic enzymes are much less effective in altering the staining characteristics of the tissue. It is of course possible that additional factors are involved; an entanglement of chondromucoproteins with collagen (SCHUBERT, 1964; Mathews, 1967) and with glycoproteins (QUINTARELLI and Dellovo, 1967; Dunstone and Franek, 1967; Franek and Dunstone, 1967 ; and Luscombe and Phelps, 1967 a and b). Indeed, the problem of separating these macromolecules, one from the other, is a formidable one.

It has been known for some time that tissues may show a partial or complete loss of basophilia due to proteolysis. Proteolytic treatment, however, can also give rise to an enhanced basophilia of a tissue. Such enhancement of staining has been demonstrated by French and BenditT (1953), KelLy (1951, 1955) and later by a score of others. The augmentation of basophilia after proteolysis has been interpreted as resulting from the elimination of basic groups which were in competition with the cationic dye molecules for the anionic sites (carboxyl and sulfate groups) of the acid glycosaminoglycans. An enhanced basophilia was invariably seen in 
fetal structures when CMPase-incubated tissues were stained with Alcian Blue at $\mathrm{pH}$ 2.5. That this may reflect the loss of basic groups from the tissue is in accord with the observations that, when ${ }^{35} \mathrm{~S}-\mathrm{labeled} \mathrm{PP}-\mathrm{L}$ is used as the substrate in vitro and the incubation mixture is subsequently dialyzed, ninhydrin-positive material is demonstrable in the dialysates but no ${ }^{35} \mathrm{~S}$ or glucuronic acid-containing material (Dziewtatkowski, TourtellotTe, and Campo, 1967).

It is important to this argument that tissue amines form numerous intramolecular salt linkages with carboxyl and ester sulfate groups, particularly when dyes are used at an acid $\mathrm{pH}$. When sections of some tissues are exposed to brief proteolytic treatment not only the loss of amino or peptide groups makes large numbers of heretofore salt-bound carboxyl or ester sulfate groups available for dye binding, but also, by attacking peptide bonds, $\mathrm{NH}_{2}$ groups are generated which should be theoretically available for acid-dye binding. It is important to bear in mind that in tissue sections, much more than in solution, steric hindrance plays an important role in dye binding.

Complementary to the histochemical results are the findings with the ${ }^{35} \mathrm{~S}$ labeled tissues. During incubation with CMPase, as well as during subsequent staining with Alcian Blue in the presence of $0.5 M$ magnesium chloride, there was a significantly greater loss (over controls) of ${ }^{35} \mathrm{~S}$-labeled material from neonatal epiphyses. Recalling that CMPase acting on isolated PP-L gives rise to a proteinpolysaccharide which is more soluble than the original compound, it seems likely that the observed loss of the label reflects a similar effect of the enzyme on the proteinpolysaccharides of the various cartilages in situ; labeled CMPs were rendered more soluble and thus were more easily leached out. Further evidence for increased solubilization of the tissue polyanions is provided by the autoradiograms of CMPase-treated sections of ${ }^{35} \mathrm{~S}$-labeled rat fetuses. In such autoradiograms, streaks, indicating the presence of ${ }^{35} \mathrm{~S}$, were seen emanating from the various cartilages. Such streaks were not seen in autoradiograms prepared from bufferincubated sections. Taking into account the position of the slides during the drying process which followed dipping them in the photographic emulsion, it is evident that the streaks flowed downwards, as the emulsion itself must have flowed to some extent while drying. Apparently, the streaks resulted from extraction of CMPase-solubilized ${ }^{35} \mathrm{~S}$-material by the photographic emulsion. Furthermore, the autoradiograms produced by the CMPase-digested sections were fainter than those produced by the control sections. The conclusion is tenable that one effect of CMPase on the connective tissues studied is an increased solubility of the proteinpolysaccharides.

More difficult is the interpretation of the observations made with the electron microscope. On the basis of the results obtained, it is tentatively suggested that the increased affinity for electron-dense stains may be due to an increased number of amino groups in the CMPase-digested sections. 'This suggestion is based in large measure on work under way in which staining with phosphotungstic acid, under definable conditions, indicates that this heteropolyacid interacts with amino groups. Furthermore, when the semithin serial sections of the blocks utilized for electronmiscroscopy were incubated with CMPase and then stained with Bromphenol Blue, in every instance there was an enhancement of staining in the same regions as the regions in which there was an increased affinity for the 
electron dense stains. This dye is known to interact stoichiometrically with cationic sites on proteins (SILBERMAN and GLICK, 1965).

Of added interest is the unexpected finding related to the granular material which is always found in great abundance in the lacunae of the hypertrophic chondrocytes. CMPase effected an increase in Bromphenol Blue and in heavy metal staining of these granules. On the other hand, the same granules showed a great avidity for cationic dyes; they appeared brilliantly metachromatic after Azure A staining. It is noteworthy that their staining reactivity disappeared after hyaluronidase treatment. Because of this it is suggested that a major component of the granules is chondromucoprotein.

Acknowledgments. The electronmicroscopic phase of this work was carried out at the Department of Morbid Anatomy, University of Pisa. The authors are grateful to the Chairman, Professor A. Ascenzi, for his kind hospitality and to Dr. E. Bonuccr for his advice and supervision during the E.M. experiments.

\section{Addendum}

While this manuscript was in the printing process further histochemical work on human fetal jaws indicated that acid glycosaminoglycans present in the stellate reticulum of tooth germs are not sulfated but rather carboxylated. On treating sections in $\mathrm{AB}$ containing $\mathrm{MgCl}_{2}$, staining unequivocally disappeared at a concentration between 0.1 and $0.2 \mathrm{M}$, i.e. at a CEC typical for the solubilization of a $\mathrm{COOH}$-bearing compound-dye complex. In view of the fact that basophilia in this area is constantly removed by hyaluronidase digestion it is suggested that the acidic macromolecule primarily responsible for $\mathrm{AB}$ binding is hyaluronic acid. If this is the case then a reappraisal of the embryonic origin of this organ and/or more careful analytical studies of the polyanions synthesized by tissues of ectodermal origin should be carried out. Investigations along these lines are now in progress.

\section{Bibliography}

ALI, S. Y.: The degradation of cartilage matrix by an intracellular protease. Biochem. J. 93, 611-618 (1964).

- The presence of cathepsin B in cartilage. Biochem. J. 102, 10e (1967).

AMPRINo, R., e A. BAIRATI: Studi sulle trasformazioni delle cartilagini dell'uomo nell'accrescimento e nella senescenza. Z. Zellforsch. 20, 134-205 (1933).

BoNHAG, P. F.: Histochemical studies of the ovarian nurse tissues and oocytes of the milkweed bug, Onocopeltus fasciatus (Dallas). I. Cytology, nucleic acids and carbohydrates. J. Morph. $96,381-440(1955)$.

Bryant, J. H., I. G. Leder, and D. STETTEN jr.: The release of chondroitin sulfate from rabbit cartilage following the intravenous injection of crude papain. Arch. Biochem. 76, 122-130 (1958).

D'Abramo, F., and F. Lipmann: The formation of adenosine-3'-phosphate-5' - phosphosulphate in extracts of chick embryo cartilage and its conversion into chondroitinsulphate. Biochim. biophys. Acta (Amst.) 25, 211-213 (1957).

Dingle, J. T.: Studies on the mode of action of excess of vitamin A. 3. Release of a bound protease by the action of vitamin A. Biochem. J. 79, 509--512 (1961).

- Action of vitamin A on the stability of lysosomes in vivo and in vitro. In: Lysosomes, Ciba Found. Symposium (A.V.S. DE ReuCK and M. P. Cameron, eds.). London: Churchill 1963.

Dorfman, A., S. Roseman, F. E. Moses, J. Ludowieg, and M. Mayeda: The biosynthesis of hyaluronic acid by group A Streptococcus. III. Origin of the N-acetylglucosamine moiety. J. biol. Chem. 212, $583-591$ (1955). 
Dunstone, J. R., and M. D. Franek: Isolation of a glycoprotein from cartilage proteinpolysaccharide. Biochem. biophys. Res. Commun. 27, 39-45 (1967).

Duve DE, C.: Lysosomes, a new group of cytoplasmic particles. In: Subcellular particles (T. Hayashi, ed.). New York: Ronald Press 1959.

Dziewiatkowski, D. D., C. D. Tourtellotte, and R. D. Campo: Degradation of proteinpolysaccharide (chondromucoprotein) by an enzyme extracted from cartilage. In: The chemical physiology of mucopolysaccharides (G. Quintareldi, ed.). Boston: Little, Brown \& Co. 1968.

Einbinder, J., and M. Schubert: Separation of chondroitin sulfate from cartilage. J. biol. Chem. 185, $725-730(1950)$.

Fell, H. B., and E. Mellanby: The effect of hypervitaminosis A on embryonic limb-bones cultivated in vitro. J. Physiol. (Lond.) 116, 320-349 (1952).

-, and L. Thомаs: The influence of hydrocortisone on the action of excess vitamin A on limb bone rudiments in culture. J. exp. Med. 114, 343-362 (1961).

Franer, M. D., and J. Dunstone: Connective tissue proteinpolysaccharides. Fractionation of the proteinpolysaccharides from bovine nasal cartilage. J. biol. Chem. 242, 3460-3467 (1967).

French, J. E., and E. P. Benditt: Histochemistry of connective tissue. II. The effect of proteins on the selective stainings of mucopolysaccharides by basic dyes. J. Histochem. Cytochem. 1, 321-325 (1953).

Gerber, B. R., E. C. Franki.in, and M. Schubert: Ultracentrifugal fractionation of bovine nasal chondromucoprotein. J. biol. Chem. 235, 2870-2875 (1960).

GLick, M. C., and F. E. Stockdale: Differences in glycosaminoglycans derived from chick embryo chondrocytes grown in vitro and in vivo. Biochim. biophys. Acta (Amst.) 83, $61-68$ (1964).

Gross, J. I., M. B. Mathews, and A. Dorfman: Sodium chondroitinsulfate-protein complexes of cartilage. J. biol. Chem. 235, $2889-2892$ (1960).

Hofmman, P., T. A. Mashburn, K. Meyer, and B. A. Bray: Proteinpolysaccharides of bovine cartilage: I. Extraction and electrophoretic studies. J. biol. Chem. 242, 3799-3804 (1967).

Holmaren, S.: Studien über Verbreitung und Bedeutung der ehromotropen Substanz. Z. mikr.-anat. Forsch. 47, $489-521$ (1940).

Karnovsky, M. J.: Simple methods for "staining with lead" at high $\mathrm{pH}$ in electron microscopy. J. biophys. biochem. Cytol. 11, 729-732 (1961).

KeLLY, J. W.: Effects of $x$-ray and trypsin on the metachromasy of heparin basic protein combination. Biol. Bull. 101, 223 (1951).

- Suppression of metachromasy by basic proteins. Arch. Biochem. 55, 130-137 (1955).

LaURent, T. C., and J. E. ScotT: Molecular weight fractionation of polyanions by cetylpyridinium chloride in salt solutions. Nature (Lond.) 202, 661-662 (1964).

Leloir, L. F., and C. E. Cardini: Uridine nucleotides. In: The enzymes (P. D. Boyer, H. Lardy and K. Mrrback, eds.), vol. 2. New York: Academic Press 1960.

LucY, J. A., J. T. Dingle, and H. B. Fell: Studies on the mode of action of excess of vitamin A. 2. A possible role of intracellular proteases in the degradation of cartilage matrix. Biochem. J. 79, 500-508 (1961).

Luscombe, M., and C. F. Phelps: The composition and physicochemical properties of bovine nasal-septa proteinpolysaccharide complex. Biochem. J. 102, 110-119 (1967a).

- Action of degradative enzymes on the light fraction of bovine septa proteinpolysaccharide. Biochem. J. 108, 103-109 (1967 b).

Mala Wista, I., and M. Schubert: Chondromucoprotein; new extraction method and alkaline degradation. J. biol. Chem. 203, 535-544 (1958).

Marinozzi, V.: Cytochimie ultrastructurale du nucléole: RNA et proteines intranucléolajres. J. Ultrastruct. Res. 10, 433-456 (1964).

Markowitz, A., J. A. Cifonelli, and A. Dorfman: The biosynthesis of hyaluronic acid by group A Streptococcus. VI. Biosynthesis from uridine nucleotides in cell free extracts. J. biol. Chem. 284, 2343-2350 (1959). 
Mathews, M. B.: The macromolecular organization of connective tissue. In: The chemical physiology of mucopolysaccharides (G. QUINTA RELLI, ed.). Boston: Little, Brown \& Co. 1968.

-, and S. GLagov: Acid mucopolysaccharide patterns in aging human cartilage. J. clin. Invest. 45, 1103-1111 (1966).

MrLlonig, G.: Further observations on a phosphate buffer for osmium solution in fixation. Vth Int. Congr. for Electron Microscopy, vol. 2, p. 8. Philadelphia: Academic Press 1962.

MowRY, R. W.: The special value of methods that color with both acidic and vicinal hydroxyl groups in the histochemical study of mucins. With revised directions for the colloidal iron stain, the use of Alcian Blue 8GX and their combinations with the periodic acid Schiff reaction. Ann. N.Y. Acad. Sci. 106, $402-423$ (1963).

Potter, J. L., R. T. McCluskey, G. Weissmann, and L. Thomas: The removal of cartilage matrix by papain. Factors affecting the distribution of crystalline papain in vivo. J. exp. Med. 112, 1173-1193 (1960).

Quintarelli, G., and M. C. Dellovo: Mucopolysaccharide histochemistry of rat tooth germs. Histochemie 3, 195-207 (1963).

- - The chemical and histochemical properties of Alcian Blue. IV. Further studies on the methods for the identification of acid glycosaminoglycans. Histochemie 5, 196-209 (1965).

- - Age changes in the localization and distribution of glycosaminoglycans in human hyaline cartilage. Histochemie 7, 141-167 (1966).

- - The effects of Clostridium histolyticum collagenase on amino sugar-containing compound-collagen complexes. Histochemie 8, 216-218 (1967).

- J. E. Scott, and M. C. Dellovo: The chemical and histochemical properties of Alcian Blue. II. Dye binding of tissue polyanions. Histochemie 4, 86-98 (1964).

Rosenberg, L., B. Johnson, and M. Schubert: Proteinpolysaccharides from human articular and costal cartilage. J. clin. Invest. 44, 1647-1656 (1965).

Schubert, M.: Biochemical and biophysical aspects of collagen. In: Connective tissue: Intercellular macromolecules. Proc. of Symposium Sponsored by N.Y. Heart Ass. Boston: Little, Brown \& Co. 1964.

ScotT, J. E., J. Dorling, and G. Quintarelli: Differential staining of acid glycosaminoglycans by Alcian Blue in salt solutions. Biochem. J. 90, $4-5 \mathrm{P}$ (1964).

Sitberman, L., and D. Glick: Bromsulfalein as a stain for protein in tissue sections. Abs. Histochem. Soc., Philadelphia, Penn., April, 1965.

Thомas, L.: Reversible collapse of rabbit ears after intravenous papain, and prevention of recovery by cortisone. J. exp. Med. 104, 245-252 (1956).

Tountellotte, D. C., R. D. Campo, and D. D. Dziewiatkowski: Degradation of a chondromucoprotein by an enzyme extracted from cartilage. Fed. Proc. 22, No 2, 413 (1963).

Tsaltas, T. T.: Papain-induced changes in rabbit cartilage. Alterations in the chemical structure of the cartilage matrix. J. exp. Med. 108, 507-513 (1958).

Wislocki, G. B., and R. F. Sognaes: Histochemical reactions of normal teeth. Amer. J. Anat. 87, $239-275$ (1950).

\author{
G. Quintarelli \\ University of Alabama \\ Medical Center \\ Birmingham, Alabama, U.S.A.
}

